\section{Ectopic ovary: one new location}

\author{
Mounzer Dgheem, ${ }^{1}$ Hosam Salman ${ }^{2}$ \\ ${ }^{1}$ Razi Hospital, Tartous; ${ }^{2}$ Freelance \\ Pathologist, Tartous, Syria
}

\begin{abstract}
Ectopic ovarian tissue is a rare gynecologic condition. Accessory ovaries were defined as excess ovarian tissue adjacent and connected to a normal ovary, while supernumerary ovaries were described as those ovaries situated away from normal ones. The one presented here is a case of a 20 year-old unmarried woman operated for recurrent abdominal pain. During laparoscopy we found a mass $2 \times 1.5 \mathrm{~cm}$ in size in the ileum, located $80 \mathrm{~cm}$ from the ileocecal valve: the lesion was resected and an ileoileal anastomosis was performed, the anatomopathological examination of the mass proved to be ovarian tissue. The history of previous pelvic surgery with adhesiolysis, and the unusual location of the ectopic ovary, support the theory of an ovarian implant in the intestine, but the true ectopic ovary hypothesis is still probable because of the location of the ectopic ovary inside the intestinal wall. In any case, the location of ectopic ovary discussed here is unusual and perhaps unpublished before.
\end{abstract}

\section{Introduction}

Ectopic ovary is a relatively uncommon condition. According to Wharton classification, ectopic ovaries can be defined as either accessory or supernumerary, depending on their relationship to a normal ovary. Accessory ovaries were defined as excess ovarian tissue adjacent and connected to a normal ovary, while supernumerary ovaries were described as those ovaries situated away from normal ovaries ${ }^{1}$ The incidence of accessory ovaries and supernumerary ovaries was reported to be very low 1:29,000-700,000 at gynecologic admissions. ${ }^{2}$

\section{Case Report}

A 20 year-old unmarried woman presented with a 3-year history of isolated lower cramplike abdominal pain. She had been operated 3 years before for appendicitis by open technique (classical McBurney incision), unfortunately, anatomopathological examination of the appendix was not made. Then, she complained of repeated abdominal pain reaching its maximum intensity in about $30 \mathrm{~min}$. to one hour lasting on average many hours, without nausea, vomiting, fever, or other symptoms. The pain became more frequent during the last 6 months before surgery. The menstrual cycle was normal, the pain was not cyclic or associated only with menstruation. In her family history, there was a brother affected by coeliac disease, some investigations for her repeated pain rarely associated with mild diarrhea were made eight months before laparoscopy that included esophagogastroduodenoscopy with multiple gastric biopsies which revealed chronic gastritis with helicobacter pylori involvement, small intestine biopsies revealed modified marsh type 3a perhaps consistent with coeliac disease. Tissue-transglutaminase antibodies (IgA anti-tTG) were normal, coeliac disease is unlikely when IgA anti-tTG is absent. $^{3}$

The physical examination during the episodes revealed tendeness on the suprapubic scar with an increase in bowl sounds. She had been again operated 4 months before for 6 cm right ovarian cyst by open technique (transverse Pfannenstiel incision). The hypothesis of post-surgical adhesions was thought, laboratory tests during crises of pain were normal, MRI of the pelvis and abdomen was normal. An exploratory laparoscopy was performed, on operation, many adhesions between the anterior abdominal wall and the omentum were found and liberated (Figure 1).

Thorough examination of the intestine revealed an ileal mass about $2 \times 1.5 \mathrm{~cm}$ in size located $80 \mathrm{~cm}$ proximal to the ileocecal valve (Figure 2). Both ovaries were in their normal location, the right ovary has a normal size, there was a $3 \mathrm{~cm}$ cyst of left ovary which was partially resected. The intestinal lesion was resected and an ileo-ileal end-to-end anastomosis was performed by re-incision of previous McBurney scar. Her postoperative course was uneventful, and she was discharged on the $3^{\text {rd }}$ postoperative day. In her last visit 6 months after surgery, the patient was still free of the abdominal pain who had suffered during the
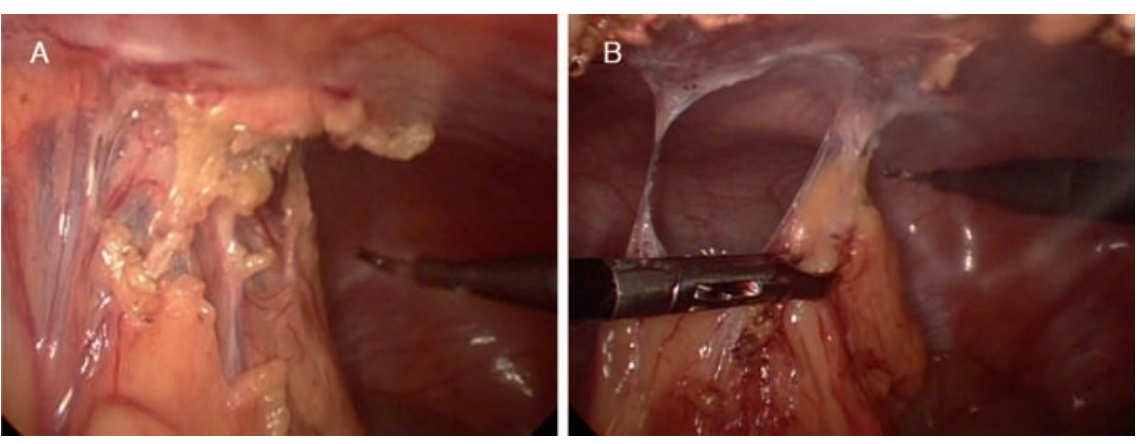

Figure 1. Exploratory laparoscopy showing adhesions between the anterior abdominal wall and the omentum (A) and their liberation (B) after operation.
Correspondence: Mounzer Dgheem, Razi Hospital, Thawra street, 45 Tartous, Syria.

Tel.Fax: +963.43223930 .

E-mail: mounzer@live.fr

Key words: ectopic ovary, laparoscopy, follicle.

Received for publication: 10 October 2013.

Revision received: 28 December 2013.

Accepted for publication: 5 January 2014

This work is licensed under a Creative Commons Attribution NonCommercial 3.0 License (CC BYNC 3.0).

(C) Copyright M. Dgheem and H. Salman, 2014 Licensee PAGEPress, Italy

Surgical Techniques Development 2014; 4:5121 doi:10.4081/std.2014.5121

past three years.

The anatomopathological examination documented an Ileum resection segment of $13 \mathrm{~cm}$ in length, cut section of the resected ileum shows macroscopically a white lesion $(2.5 \mathrm{x} 1 \mathrm{x}$ $0.8 \mathrm{~cm}$ ) at the intestinal wall contains several small cysts, the lesion is $5 \mathrm{~cm}$, and $5.5 \mathrm{~cm}$ from surgical resection margins. Microscopically the ileum segment is lined by normal mucosa, the lesion shows connective ovarian tissue stroma contains large spindle-shape fibroblasts, numerous blood vessels, follicular cells of primordial follicles, corpus albicans with several small cysts, some cysts lined by several layers of small and round cells with scanty cytoplasm and hyperchromatic nuclei (follicular cysts), some cysts lined by flattened epithelium (serous cysts), the stroma also shows multinucleated giant cells, with congested vessels, and eosinophilic material. The lesion is located within muscularis propria and serosa layers, the mesentery shows adipose tissue, and hemorrhagic areas (Figure 3 ). The anatomopathology of the left ovarian cyst was a corpus luteum cyst. 


\section{Discussion}

According to Wharton classification, ${ }^{1}$ ectopic ovaries can be defined as either accessory or supernumerary, as distinguished by their relationship to a normal ovary. By definition, the accessory or supernumerary ovaries require the presence of two normal ovaries in order to be called so. That is, accessory ovaries were defined as excess ovarian tissue adjacent and connected to a normal ovary while supernumerary ovaries were described as those ovaries situated away from normal ovaries. ${ }^{4}$ True ectopic ovary occurs according to embryonic theory as the result of abnormal separation of a small portion of the developing and migrating ovarian primordium. ${ }^{5}$ Acquired conditions of ectopic ovarian tissue was reported due to inflammation and surgical operations, the ovarian tissue which had been detached from the ovary could be implanted anywhere in the pelvic cavity. ${ }^{6}$ Supernumerary ovary was reported in the omentum, ${ }^{7-9}$ in retroperitoneum, ${ }^{10,11}$ and in the pouch of Douglas. ${ }^{12,13}$

The literature reports various cases of tumors arising in ectopic ovaries, such as serous cystadenoma, dermoid cyst, Brenner tumor, sclerosing stromal tumor, steroid cell tumor, mucinous cystadenoma, teratoma and fibroma. ${ }^{6,14-19}$ Since 1864 there have been less than 50 cases of ectopic ovary reported in the literature and only in two cases the diagnosis was established prior to the operation. ${ }^{6,14}$ Despite the strong association with pathological processes, supernumerary and accessory ovarian tissue has been notoriously difficult to diagnose preoperatively. It is usually an incidental finding or a surprise histopathological diagnosis after resection of symptomatic mass. ${ }^{11}$ The stimulation with human chorionic gonadotropin (hCG) prior to surgery was used to facilitate the location of an ectopic ovary at laparotomy in a patient who had undergone bilateral oophorectomy and adrenalectomy for metastatic breast carcinoma. ${ }^{20}$ Congenital genitourinary malformations or genetic abnormalities are associated closely with ectopic ovaries and it would be prudent to expect a urinary abnormality in the presence of ectopic ovary in about one third of cases. ${ }^{4,6,14}$

In the case we present, the pain can be explained by the mass effect on the intestinal wall which causes partial obstruction and stimulates intestinal contractions in a way mimicking the mechanism of intestinal intussusception. The history of previous pelvic surgery with adhesiolysis, and the unusual location of the ectopic ovarian tissue which has no relation with the embryonic development of the ovary and its migration, support the theory of an ovarian implant in the intestine, this is perhaps after appendectomy due to the size of this ectopic ovary and the resolution of pain after surgery, but the true ectopic ovary hypothesis is still probable because of the loca-

tion of the ectopic ovary inside the intestinal wall. In any case, this location of ectopic ovary remains unusual and unpublished before.
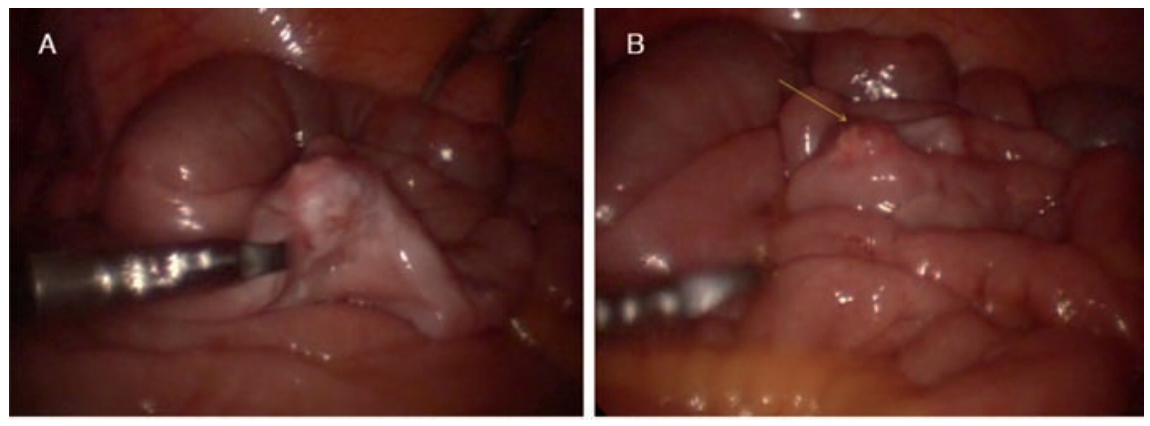

Figure 2. Examination of the intestine (A) with ileal mass (yellow arrow in B) about $2 \times 1.5$ $\mathrm{cm}$ located $80 \mathrm{~cm}$ proximal to the ileocecal valve.
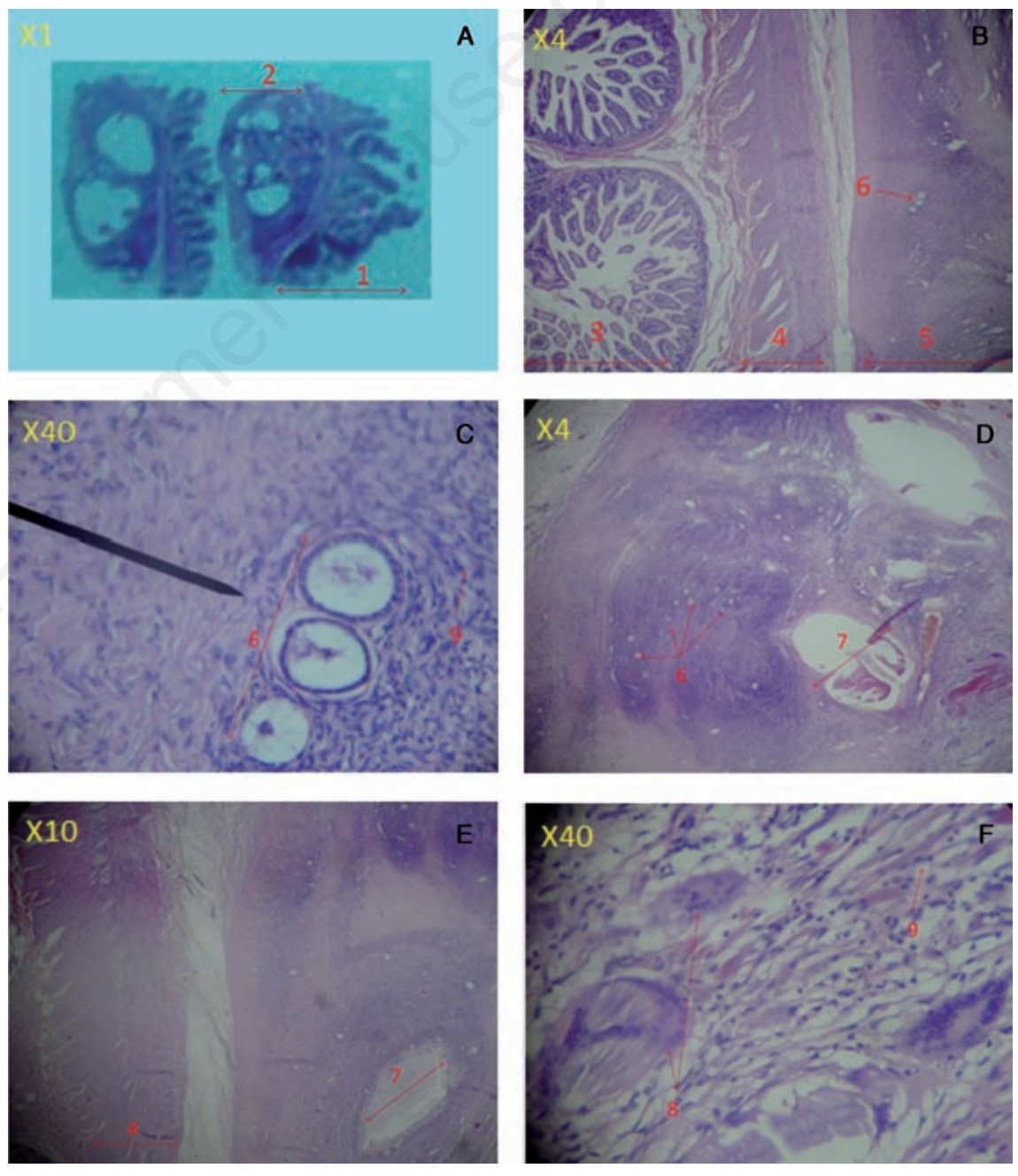

Figure 3. Anatomopathological examination of the lesion with macro- and microscopic view of the lesion (magnification factor in yellow): intestinal mucosa and submucosa (1), ectopic ovary (2), intestinal mucosa (3), muscularis propria (4), ovarian tissue (5), primordial follicles (6), atretic follicles (7), multinucleated giant cells (8), ovarian stroma (9), all visible in panels A-F. 


\section{Conclusions}

Ectopic ovary is a rare entity, we have reported one new location which was diagnosed by the anatomopathological examination of the intestinal mass after excision, it is probably a post-surgical implant secondary to the previous pelvic surgery, but a true ectopic ovary is not absolutely excluded.

\section{References}

1. Wharton L. Two cases of supernumerary ovary and one of accessory ovary, with an analysis of previously reported cases. Am J Obstet Gynecol 1959;78:1101-19.

2. Vendeland LL, Shehadeh L. Incidental finding of an accessory ovary in a 16-yr-old at laparoscopy. J Reprod Med 2000;45:4358.

3. Lock RJ, Stevens S, Pitcher MC, Unsworth DJ. Is immunoglobulin A anti-tissue transglutaminase antibody a reliable serological marker of coeliac disease? Eur J Gastroen Hepat 2004;16:467-70.

4. Albayrak M, Çakır Güngör AN, Ozer A, et al. True ectopia of left ovary with left renal agenesis: a case report. Available from: http://smyrnatipdergisi.com/dosyalar_uplo ad/belgeler/True\%20ectopia1354441037.pd f

5. Printz JL, Choate JW, Townes PL, Harper RC. The embryology of supernumerary ovaries. Obstet Gynecol 1973;41:246-52.

6. Lim MC, Park SJ, Kim SW, et al. Two dermoid cysts developing in an accessory ovary and an ectopic ovary. J Korean Med Sci 2004;19:474-6.

7. Kuga T, Esato K, Takeda K, et al. A supernumerary ovary of the omentum with cystic change: report of two cases and review of the literature. Pathol Int 1999;49:566-70.

8. Peedicayil A, Sarada V, Jairaj P, Chandi SM. Ectopic ovary in the omentum. Asia Oceania J Obstet Gynaecol 1992;18:7-11.

9. Kriplani A, Takkar D, Karak A, Ammini A. Unexplained absence of both fallopian tubes with ovary in the omentum. Arch Gynecol Obstet 1995;256:111-3.

10. Kim T, Lee H, Chung $S$, et al. How should ectopic ovaries managed? Available from: http://www.webmedcentral.com/article_vie w/3055

11. Cohen JA, Holzman. A giant ectopic ovary. J Laparoendosc Adv A 2001;11:31-5.

12. Kusaka M, Mikuni M. Ectopic ovary: a case of autoamputed ovary with mature cystic teratoma into the cul-de-sac. J Obstet Gynecol Re 2007;33:368-70.
13. Cheung VYT. Accessory ovary. J Obstet Gynaecol Can 2010;32:107.

14. Sharatz SM, Treviño TA, Rodriguez L, West JH. Giant serous cystadenoma arising from an accessory ovary in a morbidly obese 11-year-old girl: a case report. J Med Case Rep 2008;2:7.

15. Heller DS, Harpaz N, Breakstone B. Neoplasm arising in ectopic ovaries: a case of Brenner tumor in an accssory ovary. Int J Gynecol Pathol 1990;9:185-9.

16. Andrade LA, Gentilli AL, Polli G. Sclerosing stromal tumor in an accessory ovary. Gynecol Oncol 2001;81:318-9.

17. Roth LM, Davis MM, Sutton GP. Steroid cell tumor of the broad ligament arising in an accessory ovary. Arch Pathol Lab Med 1996;120:405-9.

18. Kamiyama K, Moromizato H, Toma T, et al. Two cases of supernumerary ovary: one with large fibroma with Meig's syndrome and the other with endometriosis and cystic change. Pathol Res Pract 2001;197:84751.

19. Whitaker C, Tawfik 0, Weed J. Serous cystadenofibroma arising in an ectopic ovary. Kans Med 1997;98:24-6.

20. Kosasa TS, Griffiths CT, Shane JM, et al. Diagnosis of a supernumerary ovary with human chorionic gonadotropin. Obstet Gynecol 1976;47:236-7. 